\title{
Temperature-dependent temporal variation in the size and growth of Thames estuary smelt Osmerus eperlanus
}

\author{
Michael Power ${ }^{1, *}$, Martin J. Attrill ${ }^{2}$ \\ ${ }^{1}$ Department of Biology, University of Waterloo, Waterloo, Ontario N2L 3G1, Canada \\ ${ }^{2}$ Marine Biology \& Ecology Research Centre, School of Biological Sciences, University of Plymouth, Drake Circus, \\ Plymouth PL4 8AA, UK
}

\begin{abstract}
Long-term monitoring data collected in the Thames estuary, UK, were used to investigate inter-annual trends in year-end size and growth rate of smelt Osmerus eperlanus (L.). Patterns were related to variations in the thermal opportunity for growth, defined in terms of temperaturedependent cumulative degree-days at estuarine temperatures $\geq 5^{\circ} \mathrm{C}$. Year-end size was positively correlated to the thermal opportunity for growth, whereas growth rate was negatively correlated. Cohort-specific comparisons of estuarine growth patterns indicated significant differences in starting sizes, possibly related to the influences of temperature on early larval development. Interannual differences in within-estuary growth rate as a function of cumulative degree-days were found and suggested thermally dependent growth. Smelt in normal and warm years showed similar rates of growth that differed significantly from rates observed in cold years. Reductions in the proportions of older fish in warm years were also found and interpreted in the context of spatial segregation patterns found in freshwater environments. Overall results suggest that use of mid-estuarine environments during larval development and migration to colder outer-estuarine areas are growth/maturation optimization strategies that enhance individual fitness. Thus, smelt migration phenologies in the Thames estuary appear to be driven by short-term variations in the suitability of thermal habitat.
\end{abstract}

KEY WORDS: Temperature · Osmerus eperlanus · Thames estuary · Growth rates · Climate variation · Habitat partitioning · Growth opportunity

\section{INTRODUCTION}

The fish communities of northern temperate estuaries are dominated by the juveniles of marine species (Kennish 1990). As a result, estuaries are described as important nursery areas (Thiel \& Potter 2001) and have been shown to make significant contributions to marine stock recruitment (Elliott et al. 1990). Relatively few species, however, complete their life-cycle within northern temperate estuaries because estuarine conditions are generally not conducive to spawning and early larval development (Dando 1984). In particular, temperature may limit the suitability of estuaries for many fishes (Attrill \& Power 2002, 2004). Nevertheless, temperature has been implicated as a critical community-structuring variable and determinant of movement patterns. In the Thames estuary, UK, there is evidence for facultative estuarine use by the juveniles of many species in response to climate-induced temperature differentials between adjacent estuarine and nearshore marine environments (Attrill \& Power 2002). Migration phenologies have also been related to estuary and offshore temperature differentials (Sims et al. 2004) and the temporal migration patterns of estuarine fishes in the River Thames have been interpreted as a thermal resource separation response limiting potential competition between functionally or taxonomically similar species (Attrill \& Power 2004). 
Anadromous smelt Osmerus eperlanus (L.) are present in estuarine and nearshore environments throughout Europe, from the northern coasts of Russia, through the Baltic and the western coasts of Europe including Ireland, to Vigo in western Spain (Nellbring 1989). In most environments, the species is of low commercial interest, although in some estuaries (e.g. Thames; Wheeler 1979) the smelt fishery was historically important (Hutchinson \& Mills 1987). Nevertheless, smelt can dominate the fish community. For example, smelt represent $>90 \%$ of total mean abundance in the Elbe estuary in Germany (Kafemann et al. 1996). Furthermore, smelt are regarded as being sensitive to pollution and, therefore, are good indicators of overall estuarine water quality (Thomas 1998). In the Thames estuary, smelt numbers were reduced to near zero by poor water quality in the 1950s (Wheeler 1979, Thomas 1998), but rapid recolonization occurred after water quality improvements in the 1960s and early 1970s. Recent documented changes in water quality in the Thames estuary, however, have not been associated with concomitant increases in smelt abundances (Thomas 1998), suggesting that other environmental variables now regulate the success or presence of smelt populations in the estuary.

Among the environmental factors known to directly influence smelt populations is temperature. In the Thames, for example, mean annual abundances are negatively correlated with mean annual estuarine water temperatures (Attrill \& Power 2004). In contrast, size is positively correlated to the North Atlantic Oscillation Index, with high index values corresponding to warm, wet and stormy winters in the northeast Atlantic Ocean (Attrill \& Power 2002). Temperature has also been associated with increased smelt mortality rates in freshwater (Ivanova 1980) and estuarine (Pronier \& Richard 1998) environments and shown to affect the timing of annual spawning runs (Hutchinson \& Mills 1987).

More generally, changes in temperature may act as important cues to fish movement or habitat selection (e.g. Magnuson et al. 1979, Attrill \& Power 2004, Sims et al. 2004) and may be associated with facultative exploitation of temperature gradients within and between habitats (Attrill \& Power 2004). Temperature is also an important determinant of survival and fitness as a result of its influence on organism physiology. Therefore, fish will select habitats with temperatures that facilitate the maximization of seasonal growth and other fitness-enhancing traits (e.g. gonad maturation). Integrated over periods of time, however, it will be the accumulation of time spent at, or close to, optimum or preferred temperatures, rather than temperature per se, which ultimately controls physiological responses when temperature acts as a controlling factor (Thorpe et al. 1989). For example, temperatures may be too high or too low to accommodate growth during substantial portions of any growing season. As a result, correlations between size-at-age and indices of the suitability of the growing season, or thermal opportunity for growth, will be better than correlations with temperature alone. Accordingly, significant correlations between size and the thermal opportunity for growth have been demonstrated for a wide variety of species including: anadromous Atlantic salmon Salmo salar (Thorpe et al. 1989), estuarine Atlantic silverside Menidia menidia (Conover \& Present 1990) and freshwater yellow perch Perca flavescens (Power \& van den Heuvel 1999).

To investigate the influence of temperature-induced inter-annual variations in the thermal opportunity for growth on estuarine smelt year-end size $(\mathrm{cm})$ and seasonal growth rates $\left(\mathrm{mm} \mathrm{d}^{-1}\right)$, this study used highresolution temporal sampling data collected from power station monitoring surveys of the mid-estuary of the River Thames. Data were used to test the hypotheses that: (1) inter-annual variations in year-end size (cm) were positively correlated with changes in the thermal opportunity for growth within the estuary, and (2) as a consequence of year-end (seasonal) asymptotic growth patterns that lower the scope for growth as size increases (Brett 1979), growth rates $\left(\mathrm{mm} \mathrm{d}^{-1}\right)$ were negatively correlated with changes in thermal opportunity for growth within the estuary.

\section{MATERIALS AND METHODS}

Fish sampling and environmental data. All smelt samples were obtained from fish entrained by the operation of cooling water intakes at West Thurrock Power station, located on the north bank of the Thames mid-estuary approximately $36 \mathrm{~km}$ downstream from London Bridge. Full details of the sampling methodology are given in Thomas (1998) and briefly described here. Fish entered the cooling water intake through culverts located below the low tide water level and were removed by rotating band screens for flushing back to the estuary via a gutter system. Samples were collected approximately every 2 wk over a 16 yr period (1977-1992) by fitting square framed nets (1 mm mesh size) to the gutter (Thomas 1998). Sampling began $1 \mathrm{~h}$ before low water and continued for a $4 \mathrm{~h}$ period. Nets were emptied every $30 \mathrm{~min}$ and all fish were identified, counted and measured for total length $(\mathrm{mm})$ (Power et al. 2000). When extremely large samples were obtained, a randomly selected sub-sample of the catch was measured. As seasonal variation in electricity demand affected cooling water requirements and the number of operating intake pumps, catch size was 
adjusted for the effect of water volume to facilitate temporal comparisons. Adjustment involved converting the actual number of fish entrained to the number entrained per $500000 \mathrm{~m}^{3}$ of filtered water (Thomas 1998) and hereafter catch is expressed on a catch per unit effort basis.

Daily estuarine temperature $\left({ }^{\circ} \mathrm{C}\right)$ data were obtained from Environment Agency (UK) databases (Attrill \& Power 2000). Where temperature records were incomplete, linear interpolation was used to infer missing temperatures from adjacent daily means. Data were used to compute degree-days at temperatures $\geq 5^{\circ} \mathrm{C}$ for each day, from which cumulative degree-days $\geq 5^{\circ} \mathrm{C}$ were computed following standard climatological methods as the difference between mean daily temperature and $5^{\circ} \mathrm{C}$ (Environment Canada 1982). The threshold of $5^{\circ} \mathrm{C}$ was selected on the basis of literature reports for the related species, rainbow smelt Osmerus mordax, which indicated an avoidance threshold of $6^{\circ} \mathrm{C}$ (i.e. fish will not actively select temperatures below that value) (Coutant 1976), maximal larval abundance in the 5 to $6^{\circ} \mathrm{C}$ range (Brandt et al. 1980) and the onset of glycerol production known to be quantitatively important in providing blood freezing resistance (Driedzic \& Ewart 2004). Physiological models of growth suggest there will be some temperature above which growth ceases (Elliott 1976). To account for the possible effects of high temperatures on growth, degree-day computations did not include consideration of days for which mean temperatures exceeded $25^{\circ} \mathrm{C}$, the upper limit used to model smelt weight growth in Lake Tjeukemeer (Mooij et al. 1994).

Degree-days were then summed over the period from March to December for each year to determine the annual thermal opportunity for growth. The start and end dates for the summation period were chosen, respectively, to coincide with the identified period of smelt spawning intensity in the UK (Hutchinson \& Mills 1987) and the end of the calendar year. Sea surface temperature data for the southwest portion of the North Sea were obtained from the German Federal Maritime and Hydrographic Agency (Bundesamt für Seeschiffahrt und Hydrographie) as a proxy for outer estuary and nearshore marine temperatures.

Age and growth analysis. Following Attrill \& Power (2002), fish from sample dates with $\mathrm{n} \geq 30$ were assigned to Age 0 and older age classes using statistical decomposition methods (Bhattacharya 1967) designed to separate sample length-frequency data into component age-specific length distributions. Correspondence between assigned age classes and the sub-sample of aged fish (determined from scales) was checked. Length-frequency data for individual sample dates were further used to identify first and last appearance dates in the annual catch record and determine the duration of mid-estuary residency (e.g. Attrill \& Power 2002). Length and sample date data for first and last presence dates were used to infer specific growth rates $\left(\mathrm{mm} \mathrm{d}^{-1}\right)$ for the period of estuarine residency.

For selected years for which temperatures in the estuary were below (1979), near (1982) or above (1990) the long-term annual mean (1979-1992), cohortspecific mean lengths were computed from (approximately) July of the birth year to December of the following year. Mean length data were then used to model seasonal growth patterns using a sine wave von Bertalanffy growth model (Pitcher \& MacDonald 1973):

where

$$
L_{t}=L_{\infty}\left(1-\mathrm{e}^{-K_{1}}\right)
$$

$$
K_{1}=C \sin \left(\frac{2 \pi(t-s)}{52}\right)+K\left(t-t_{0}\right)
$$

where $L_{\infty}$ is the asymptotic length towards which fish grow, $L_{t}$ is the length of the fish at age $t, K_{1}$ is the von Bertalanffy growth rate parameter $(K)$ modified by the addition of a sine function that is expressed in terms of weeks, $C$ and $s$ are constants controlling the magnitude of sine wave oscillations and the starting point for the sine wave, and $t_{0}$ is the hypothetical age-at-zero length. The rising and declining portions of the sine wave alternatively simulate rapid summer growth and the winter cessation of growth (Pitcher \& MacDonald 1973). As the asymptotic length is approached, $K$ increases, $\mathrm{e}^{-K_{1}}$ approaches 1 and the sine wave oscillations are damped. Models were estimated using nonlinear regression and residuals examined for statistical adequacy as described in Bates \& Watts (1988). Testing of significant differences between estimated von Bertalanffy models was completed with Bonferroni adjusted significance levels applied to all-ways comparisons among model parameters using an analysis of the residual sums of squares and the $F$-statistic based Chow test (Haddon 2001).

Statistical analysis. Variations in water temperature imply that some temperatures will be more optimal for growth than others, with the accumulation of more favourable temperatures leading to better growth (e.g. Conover \& Present 1990). Accordingly, linear regression was used to determine the significance of relationships between cohort-specific mean lengths $\left(L_{t}\right)$ and cumulative degree-days $\geq 5^{\circ} \mathrm{C}\left(C D_{t}\right)$ estimated from the daily temperature record as:

$$
L_{t}=b_{0}+b_{1} C D_{t}
$$

where $t$ is an index of time and $b_{0}$ and $b_{1}$ are the regression estimated model coefficients.

Linear regression was also used for studying annual trends in year-end size $(\mathrm{cm})$ and seasonal Age 0 growth rates $\left(\mathrm{mm} \mathrm{d}^{-1}\right)$ in relation to cumulative 
degree-days $\geq 5^{\circ} \mathrm{C}$. 'Seasonal' was defined as the period of estuarine residency for larval smelt from the date of initial 'catchability' (typically July) to December of the birth year. All regression residuals were statistically validated with autocorrelation, heteroscedasticity and normality testing following methods defined in Zar (1999). Analysis of covariance (ANCOVA) was used to establish the overall statistical significance of differences between estimated regression models, with adaptations of Tukey's HSD test being used for multiple comparisons among regression estimated slopes and intercepts (Zar 1999). The KolmogorovSmirnov test was used to determine differences in length-frequency distributions of fish caught in a series of years with temperatures below (1985 to 1987) and above $(1989$ to 1990,1992$)$ the long-term mean annual estuarine temperature as computed from available temperature data (1977 to 1992). Significant differences between computed coefficients of variation were determined using the $z$-based statistical procedure described in Zar (1999). Elsewhere, standard statistical procedures ( $z$ - or $t$-tests) were implemented as recommended in Zar (1999). Maximal Type-I error rates in all statistical analyses were set at $\alpha=0.05$.

\section{RESULTS}

Over the sample period, data for 12 of 16 yr could be used for analysis, the exceptions being 1977-1978, when no length data were recorded, and 1991-1992 when sampling was completed only during part of the year (spring and late summer). The majority of fish (99.0\%) captured during sampling were Age 0 and

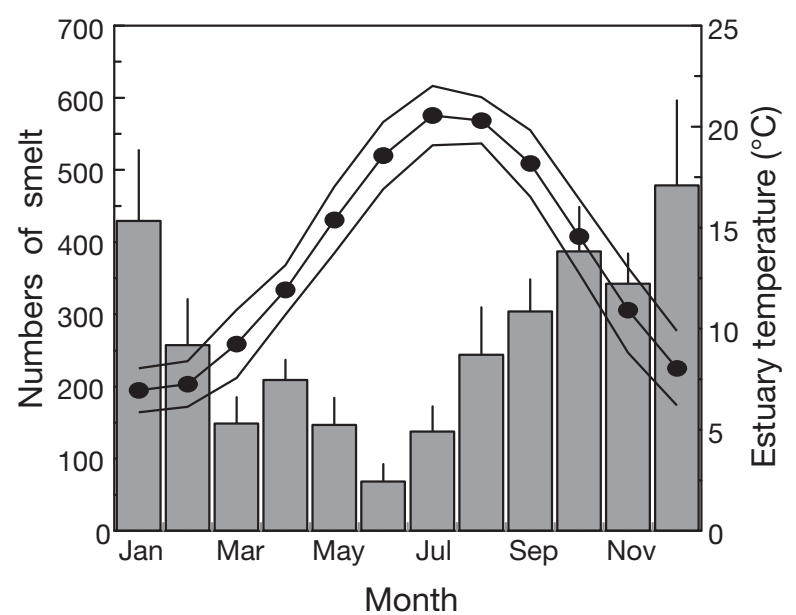

Fig. 1. Osmerus eperlanus. Monthly mean $( \pm \mathrm{SD})$ of number of smelt (grey bars) sampled per $500000 \mathrm{~m}^{3}$ of cooling water extracted from the River Thames mid-estuary and associated mean monthly temperatures $\left(-\bullet_{-}\right.$; SD plotted as solid lines around the mean) for the period 1977 to 1992

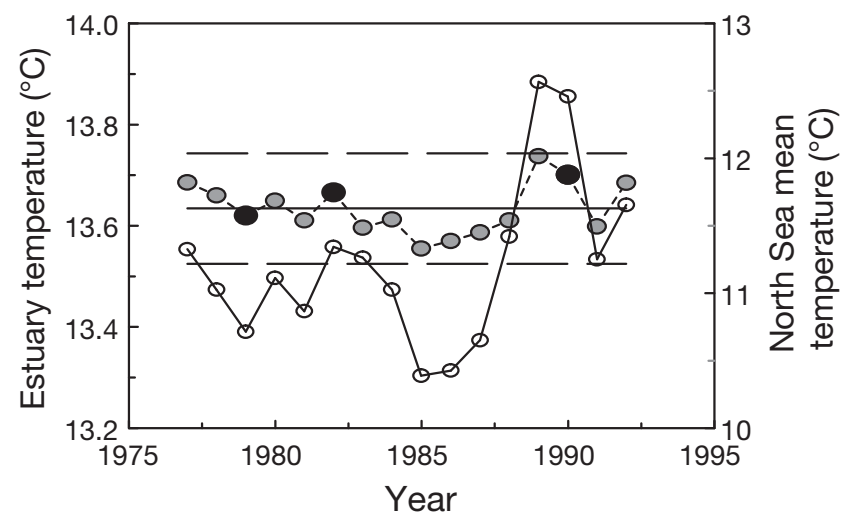

Fig. 2. Osmerus eperlanus. Average annual (1977 to 1992) temperatures in the River Thames mid-estuary $(\mathbf{0}, 0)$, and the southern North Sea $(\bigcirc)$. Horizontal dashed and solid lines: long-term mean estuary temperature and $\pm 95 \%$ confidence intervals, respectively. 0 : cohort years used to model cold (1979), normal (1982) and warm (1990) year growth patterns

Age 1. There was strong seasonality in mean standardized catch (number per $500000 \mathrm{~m}^{3}$ of extracted cooling water), the lowest mean sample sizes being recorded in June and the highest in December and January, and an inverse relationship $\left(r^{2}=0.521, d f=10, p=0.041\right)$ between the pattern of monthly catch and temperature (Fig. 1).

Average temperature $( \pm \mathrm{SD})$ over the study period (1977-1992) was $13.63 \pm 0.05^{\circ} \mathrm{C}$. Variations in temperature were significantly correlated with cumulative degree-days $\geq 5^{\circ} \mathrm{C}\left(\mathrm{r}^{2}=0.977, \mathrm{df}=16, \mathrm{p}<0.001\right)$. Temperatures were below and above average values for significant periods (Fig. 2), notably in 1983 to 1988 when average annual temperatures were at their lowest values, and in 1989, 1990 and 1992, when average annual temperatures were at their highest values as a result of drought in the southeast of England (Attrill \& Power 2000). A similar temperature pattern was noted for the southern North Sea in the same period (Fig. 2) and there was a significant correlation between average annual temperatures in both environments $\left(\mathrm{r}^{2}=\right.$ 0.847, df $=15, \mathrm{p}<0.001$ ). Nevertheless, the interannual coefficient of variation for temperature was higher in the North Sea (5.5\%) and significantly different $(p<0.001)$ than the value found for the Thames mid-estuary $(0.4 \%)$ over a similar period.

Temperature differentials between the Thames midestuary and the southern portion of the North Sea varied seasonally, with the smallest differences being found in the September to February period and the largest differences being found in the March to August period. The seasonal variation in temperature differentials was correlated to mean monthly catch (ind. sample ${ }^{-1}$ ), which declined as the estuary warmed relative to the North Sea $\left(r^{2}=0.873, d f=10, p<0.001\right)$. 


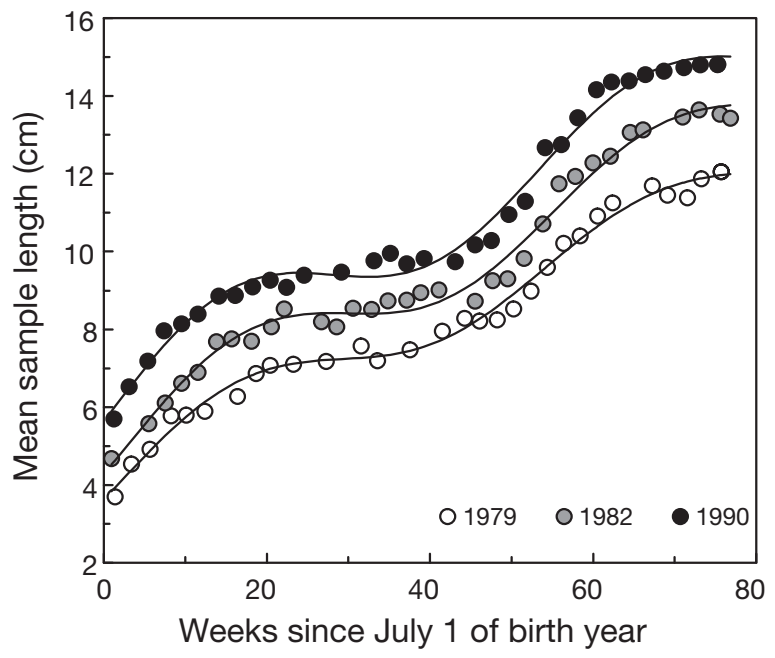

Fig. 3. Osmerus eperlanus. Estimated von Bertalanffy sine wave growth models for the 1979 (cold: $\mathrm{r}^{2}=0.991, \mathrm{df}=25, \mathrm{p}<$ 0.001), 1982 (normal: $\mathrm{r}^{2}=0.988, \mathrm{df}=28, \mathrm{p}<0.001$ ) and 1990 (warm: $\mathrm{r}^{2}=0.989, \mathrm{df}=28, \mathrm{p}<0.001$ ) cohorts. Mean total lengths at successive sample dates for Age 0 fish for the period from July 1 of the birth year to December of the following year are shown

The sine wave von Bertalanffy growth models estimated from sequentially sampled cohort-specific mean lengths for the years 1979-1980 (cold), 1982-1983 (normal) and 1990-1991 (warm) explained $\geq 98.8 \%$ of observed variations in length (Fig. 3). Estimated models were significantly different from one another. The Chow test $F$-statistic for all paired model comparisons was $\geq 108.9$ ( $p<0.001$ ), as compared with the Bonferroni corrected significance level $(p=0.017)$ for simultaneous comparisons. Tests of regression model residuals confirmed that they were normal, independent and homoscedastic. Estimated model parameters are reported in Table 1.

Cohort length-at-age was significantly correlated to cumulative degree-days $>5^{\circ} \mathrm{C}$ (Fig. 4), with $\mathrm{r}^{2} \geq 0.981$ in all cases. Residuals testing confirmed the statistical adequacy of the estimated models. Statistical tests of

Table 1. Osmerus eperlanus. Estimated von Bertalanffy sine wave growth model parameters for juvenile smelt sampled from the midestuary of the River Thames for 1979 (cold), 1982 (normal) and 1990 (warm) cohorts. $L_{\infty}$ : asymptotic length; $K$ : von Bertalanffy growth rate parameter expressed (in wk); $t_{0}$ : hypothetical age-at-zero size; $s$ and $C$ : constants defining the sine wave starting point and oscillation magnitude

\begin{tabular}{|ccccccc|}
\hline Cohort & $L_{\infty}$ & $K$ & $t_{0}$ & $s$ & $C$ & $\mathrm{r}^{2}$ \\
\hline 1979 & 29.648 & $4.644 \times 10^{-3}$ & -30.963 & 3.335 & 0.034 & 0.991 \\
1982 & 39.222 & $3.680 \times 10^{-3}$ & -36.494 & 4.099 & 0.032 & 0.988 \\
1990 & 45.130 & $3.261 \times 10^{-3}$ & -43.423 & 2.246 & 0.031 & 0.989 \\
\hline
\end{tabular}

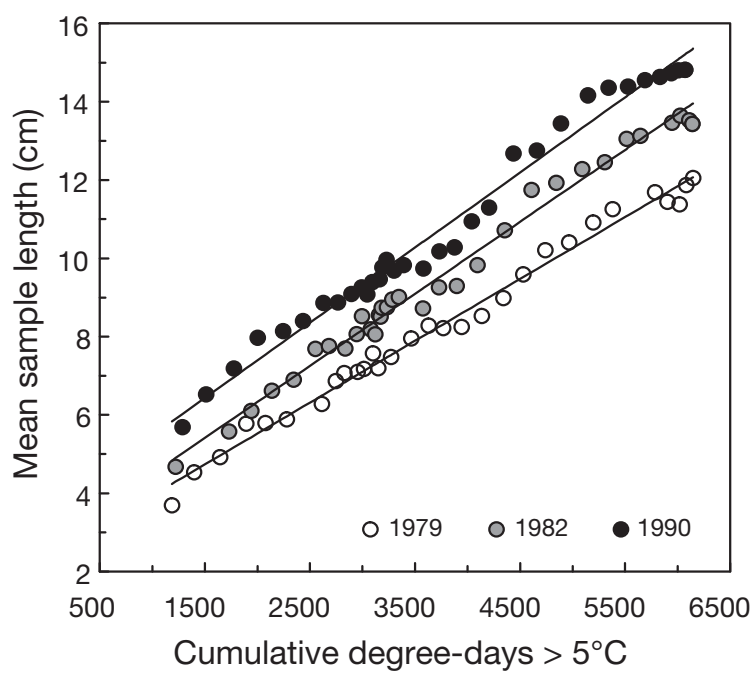

Fig. 4. Osmerus eperlanus. Variations in length as a function of cumulative degree-days $\geq 5^{\circ} \mathrm{C}$ for the 1979 (cold: $\mathrm{r}^{2}=0.988$, $\mathrm{df}=28, \mathrm{p}<0.001), 1982\left(\right.$ normal: $\left.\mathrm{r}^{2}=0.988, \mathrm{df}=31, \mathrm{p}<0.001\right)$ and 1990 (warm: $\mathrm{r}^{2}=0.981, \mathrm{df}=31, \mathrm{p}<0.001$ ) cohorts. All model intercepts differ significantly from one another $(\mathrm{p}<$ 0.001), whereas only the 1979 cohort model slope is unique

the equivalence of model slopes and intercepts (ANCOVA) rejected the hypotheses of common slopes $\left(F=19.66\right.$, df: $\left.V_{1}=2, V_{2}=92, \mathrm{p}<0.001\right)$ and common intercepts $\left(F=342.21\right.$, df: $\left.v_{1}=2, v_{2}=92, \mathrm{p}<0.001\right)$. Multiple comparisons of slopes completed using Tukey's HSD test indicated similar slopes for the 1982 (normal) and 1990 (warm) cohort models ( $p=0.500$ ) that differed significantly from the estimated slope for the 1979 (cold) cohort model $(\mathrm{p}<0.001)$. Multiple comparisons of model intercepts indicated all intercepts differed significantly (Tukey's HSD p < 0.001), with the intercept for the coldest year (1979) being smallest and the intercept for the warmest year (1990) being largest.

Comparisons of catch from cold (1985 to 1987) and warm (1989-1990, 1992) years further indicated significant declines in the numbers of Age 1 fish. The mean standardized catch of Age 1 fish declined by $57 \%$ and the proportion of Age 1 individuals was reduced from $24 \%$ of total catch in cold years to $12 \%$ of total catch in warm years. Overall, however, there was no significant relationship between the standardized mean catch of all age-classes and temperature $\left(\mathrm{r}^{2}=0.449\right.$, df $=13, \mathrm{p}=0.095$ ).

Mean year-end size $(\mathrm{cm})$ and seasonal growth rates $\left(\mathrm{mm} \mathrm{d}^{-1}\right)$ were significantly correlated with cumulative degree-days $\geq 5^{\circ} \mathrm{C}$, with year-end size (Fig. 5) increasing as cumulative degree-days increased $\left(\mathrm{r}^{2}=0.776\right)$ and growth rate (Fig. 6) declining as cumulative degree-days increased $\left(r^{2}=0.895\right)$. Statis- 


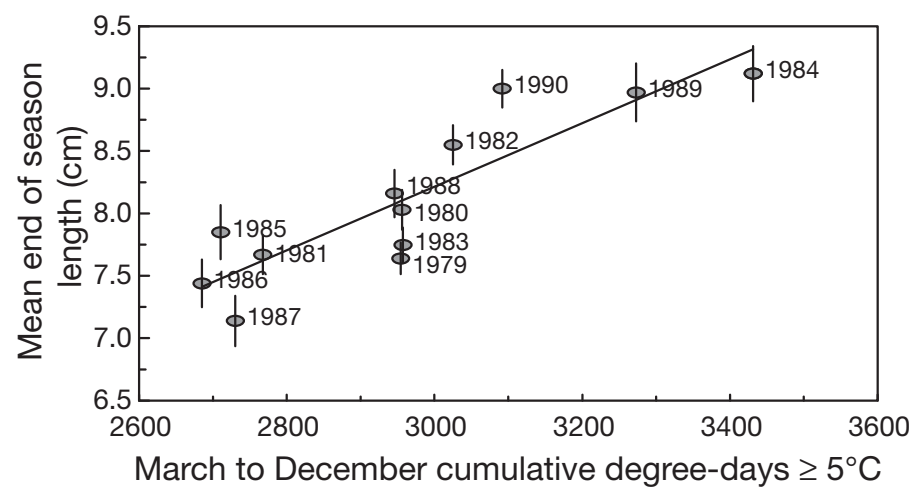

Fig. 5. Osmerus eperlanus. Mean year-end size $( \pm \mathrm{SD})$ as a function of March to December cumulative degree-days $\geq 5^{\circ} \mathrm{C}$ for smelt captured in the River Thames mid-estuary 1979 to $1990\left(r^{2}=0.777, d f=10, p<0.001\right)$

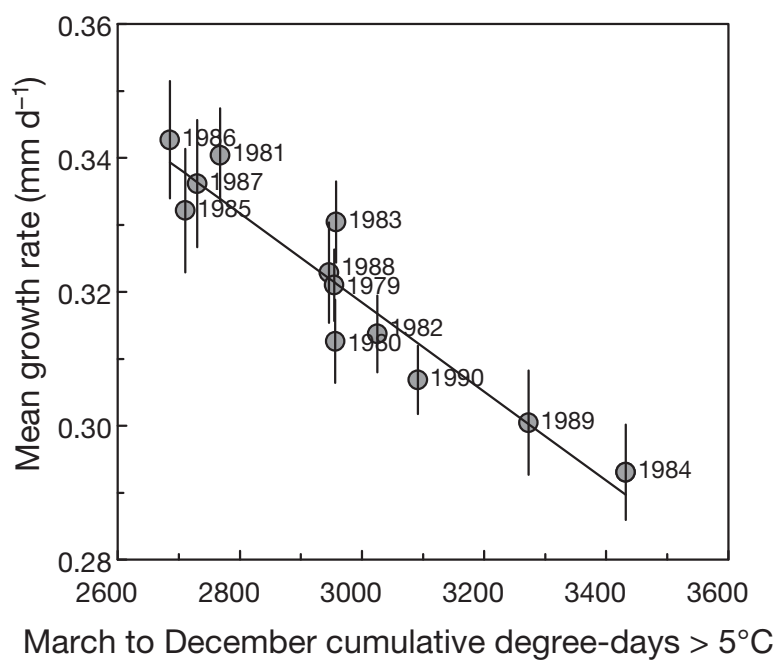

Fig. 6. Osmerus eperlanus. Mean annual growth rate $( \pm \mathrm{SD})$ during the period of estuarine residency as a function of March to December cumulative degree days $\geq 5^{\circ} \mathrm{C}$ for smelt captured in the River Thames mid-estuary 1979 to $1990\left(\mathrm{r}^{2}=\right.$ $0.895, \mathrm{df}=10, \mathrm{p}<0.001$ )

tical tests of regression model residuals confirmed that all residuals were normal, independent and homoscedastic.

\section{DISCUSSION}

Data collected for the period 1979 to 1990 on smelt year-end size and seasonal growth in the mid-estuary of the River Thames showed considerable variability among years. Despite the potential influence of variations in abundance and high variability in estuarine physico-chemical conditions (Attrill \& Power 2000), inter-annual variations in the thermal opportunity for growth as represented by cumulative degree-days $\geq 5^{\circ} \mathrm{C}$ significantly influenced the pattern and rate of estuarine smelt growth. Estimated von Bertalanffy cohort-specific asymptotic lengths increased in warmer years, whereas growth rates $(K)$ declined. Between cohorts, year-end lengths $(\mathrm{cm})$ and seasonal growth rates $\left(\mathrm{mm} \mathrm{d}^{-1}\right)$ were correlated positively and negatively, respectively, to the thermal opportunity for growth. Taken together the data from this study provide evidence that smelt year-end sizes and seasonal growth rates co-vary with temperature-induced fluctuations in the thermal opportunity for growth in the manner predicted by study hypotheses.

In the dynamic environments of an estuary, variations in flow, channel depth and tidal influence create gradients along which environmental conditions vary (Kinniburgh 1998), thereby allowing individuals to select conditions closer to required physiological optima for the species (Tracy \& Christian 1986, Wildhaber \& Crowder 1990). As intra-specific variations in size-at-age are often observed in response to differences in environmental conditions (Stearns 1992), the choice of a suitable thermal habitat can be critical for individual survival and fitness. Osmeridae are generally regarded as coldwater fish, with seasonal movements and depth distributions determined by temperature (Nellbring 1989). Although not estimated for Osmerus eperlanus, the preferred $\left(12.8^{\circ} \mathrm{C}\right)$ and upper incipient lethal $\left(18^{\circ} \mathrm{C}\right.$ at $11^{\circ} \mathrm{C}$ winter acclimation) temperatures for related $O$. mordax are indicative of a temperate stenotherm (Countant 1976, Evans \& Loftus 1987).

Lacustrine Age 0 osmerids, however, are known to use warmer epilimnion waters and have been reported in temperatures ranging from 13 to $14^{\circ} \mathrm{C}$ (Brandt et al. 1980) and 14.1 to $16^{\circ} \mathrm{C}$ in Lake Michigan (Tin \& Jude 1983) and 15 to $18^{\circ} \mathrm{C}$ in Lake Ladoga (Ivanova 1982). In summer, the differences in temperature preferences are known to spatially segregate juveniles from older age-classes (Dryer 1966, Ivanova 1982). Studies of vertical and horizontal disirtbutions of rainbow smelt Osmerus mordax in Cayuga Lake, New York, indicated distinct temperature-dependent movement patterns, with larger individuals moving offshore in summer when nearshore temperatures exceeded $13^{\circ} \mathrm{C}$ (Dahlberg 1981). On the basis of results reported in the literature, Evans \& Loftus (1987) concluded that freshwater smelt had a eurythermal life history with lifestage specific partitioning of lake nearshore zones into thermal strata spanning warm- (Age 0), cool- (Age 1) and coldwater (> Age 1) habitats that allowed individuals to optimally use spatial, thermal and preyresource gradients, while minimizing intra-specific interactions.

The size-related shift to colder waters seen in freshwater smelt is also seen in the seasonal abundance pat- 
terns observed in the Thames estuary. A preference for colder water in older fish appears to underpin the seasonal migration from the mid- to outer estuary beginning in March as mid-estuary temperatures warm. Although fixed-point sampling used in this study precludes direct comment on smelt migration phenologies, temporal trawling (Thomas 1998) and parasite (Munro et al. 1998) studies have documented smelt movement patterns consistent with increased seasonal use of outer estuarine areas. In particular, the deterioration of water and habitat (e.g. temperature increases) in the upper Thames estuary are known to significantly reduce seasonal smelt abundances (Munro et al. 1998) as observed in the middle estuary. Furthermore, Kinniburgh (1998) has documented a temperature gradient along the estuary, with colder waters occurring only in the lower estuary. A temperature-dependent presence or absence of smelt from the middle estuary, therefore, can only be interpreted in the context of spatial re-distribution within the estuary as consistent with movement to the lower estuary.

In freshwater environments there is a marked vertical migration to cooler habitats (Brandt et al. 1980). The Thames, however, is a well-mixed estuary with no variation in salinity or temperature over the vertical profile (Kinniburgh 1998) that would permit effective use of cooler habitats as a result of vertical redistribution. In many other estuarine environments horizontal migration along the estuarine temperature gradient also appears to be favoured over vertical migrations, possibly because of mixing or depth limitations as in the Thames. For example in the Curonian Lagoon, Lithuania, smelt larvae move from warmer, lagoonal nursery waters to cooler Baltic waters, typically by July (Žiliukiene 2002). In Miramichi Bay, New Brunswick, juvenile anadromous rainbow smelt Osmerus mordax segregate spatially along an implied temperature gradient, with larger smelt being found farthest out (McKenzie 1964). Spatial separation between Age 0 and older smelt has also been demonstrated in the Elbe estuary, where it has been interpreted as a mechanism for the avoidance of intra- and inter-specific biological interactions (Thiel 2001).

Estuaries are favoured larval nursery areas, combining an abundance of food, lowered larval predation risks and the warmer temperatures necessary to optimize growth (Attrill \& Power 2004). However, as smelt age, the fitness advantages of the estuary appear to decline, particularly in summer when temperatures in the upper and middle estuary approach or exceed the probable incipient lethal limit for smelt. High temperatures are known to adversely affect lacustrine and estuarine smelt populations, with high mortalities having been recorded during hot summers (Ivanova 1980, Pronier \& Rochard 1998). Age 1 and older smelt may also be unable to tolerate the marked temperature fluctuations that can occur in shallower inshore areas (Nsembukya-Katuramu et al. 1981). Accordingly, there are fitness advantages associated with the age-related move to colder waters reflected in the proportional importance of Age 1 fish in the catch of warmer years.

A second trigger for movement to colder waters may be related to the onset of sexual maturation. In freshwater smelt Osmerus eperlanus, Ivanova \& Volodin (1981) concluded that sexual maturation rates varied with cumulative degree-days and the rate of sexual maturation was subject to phenotypic variation. The switch to cooler water habitats would lower basal metabolic demands, freeing surplus energy for gonad formation. Accordingly, thermally dependent use of estuarine habitats by smelt may be an important behavioural mechanism facilitating maximum larval growth and subsequent gonad development in thermally heterogeneous environments (e.g. Biette \& Geen 1980). As a consequence, facultative use of estuarine areas would play an important role in determining eventual levels of smelt production.

Comparisons of size under differential temperature regimes in other studies have shown the same pattern of temperature-dependent increases in size found in the Thames estuary. Warmer years resulted in increased smelt size in the Vistula Lagoon, Poland (Trella 2003), the Curonian lagoon, Lithuania (Žiliukiene 2002), and a Norwegian fjord lake (Næsje et al. 1987) compared with that in cooler years. Comparisons of size-at-age of smelt from the cooler Shannon and warmer Waterford estuaries in Ireland also indicated that larger fish occurred in warmer estuaries (Doherty \& McCarthy 2004). Although this study only correlates size with cumulative degree-days, the seasonal pattern of the degree-days may account for some of the unexplained variation in estimated year-end size and growth rate estimates, with increased early season growth opportunities being more important for overall size increases than similar late season opportunities.

Size differences between warm and cold years may also relate to temperature-dependent spawning (Nellbring 1989). Spawning initiation has been reported to begin at 4 to $6^{\circ} \mathrm{C}$ in Poland (Žiliukiene 2002), 4 to $6^{\circ} \mathrm{C}$ in Russian hydroelectric reservoirs (Kuznetsov 1976), $>5^{\circ} \mathrm{C}$ in the River Cree, Scotland (Hutchinson \& Mills 1987 ) and 4 to $7^{\circ} \mathrm{C}$ in Canada (McKenzie 1964). Temperature generally has pervasive influences on larval and egg development rates (Blaxter 1992). For smelt in particular lower temperatures can delay or prolong spawning and egg development (Nellbring 1989) and have been associated with below average larval sizes (Žiliukiene 2002). In this study, tests of cumulative degree-day size-at-age models indicated significant differences between all model intercepts. Differences 
between warm and cold years, therefore, may relate more to the effects of early seasonal temperatures on smelt larval development and size than to later (July onwards) within-estuary differences in cumulative degree-days, with early season differences in growth being maintained throughout the growing season. Nevertheless, differences in estimated growth rates between cold and other years, and the strong correlations with thermal growth opportunity, suggest thermally dependent growth occurs within the estuary.

Smelt year-class variations have been correlated with mean July and August air temperatures in longterm studies of recruitment variability in Swedish lakes, where Nyberg et al. (2001) suggested that spring-spawning smelt are able to adjust to varying early growing season temperature and food conditions. In studies of Russian reservoir smelt populations, thermal regime and food availability during spring larval development have been found to be the most important determinants of smelt growth rates and subsequent population dynamics (Ivanova 1982). The influence of water temperature, however, appears greatest during early larval stages, with food availability becoming more important as individuals approach first maturation. Accordingly, food availability is thought to be a more important determinant of year-class strength (Nellbring 1989, Strelnikova \& Ivanova 1982) than early seasonal growth (Ivanova 1982).

Temperature-correlated fluctuations observed in the year-class strength in other species (e.g. Ottersen \& Loeng 2000) suggest density-dependent growth may explain part of the observed negative correlation between growth rate and the opportunity for growth in the Thames estuary. Lake removal experiments with smelt, however, have reported that smelt growth rates did not change appreciably as a result of mass removals that significantly reduced smelt density and biomass (Horppila et al. 1996). Furthermore, in the Thames a non-significant correlation existed between effort-standardized mean catch and temperature. Accordingly, temperature-dependent declines in smelt growth rates are more likely to result from the physiological effects of temperature on metabolic demands, the rate of food consumption and growth efficiency. During warmer years metabolic demands may have increased such that estuarine smelt were subject to food availability constraints, causing individuals to grow at rates below their physiological potential. Lower growth rates may also have resulted from the averaging effect of body-size changes on computed growth rates. With increasing body size, the scope for growth generally declines (Brett 1979). The larger sizes associated with the increased opportunity for growth (cumulative degree-days) will, therefore, effec- tively lower realized growth rates independently of any temperature-ration interactions.

Migration to the outer estuary may also have resulted in apparently lower growth rates in warmer years if temperature-dependent growth and maturation caused faster growing individuals to migrate from the middle estuary earlier in warmer years. Increases in temperature would, thus, result in a larger proportion of slower growing individuals, thereby lowering the sample-based mean growth rate used to characterize the seasonal growth rates of smelt in the middle estuary area.

Finally, the energy lost to faecal and excretory waste production varies with diet and differences in trophic habits (Jobling 2002). For carnivorous fish, the proportion of energy lost is higher than for planktivores or detritivores. Smelt larvae initially consume diatoms, moving to rotifers, copepods and successively larger zooplankton as they increase in size (Næesje et al. 1987, Nyberg et al. 2001). Size-related changes in trophic status, therefore, are probably related to an increasing proportional loss of ingested energy and reduced growth rates. Although few investigators have measured excretory losses for different fish sizes and water temperatures, excretory losses for brown trout Salmo trutta, expressed as a percentage of energy intake, increase as temperature increases and the temperature-dependent level of energy intake decreases (Elliott 1976).

\section{CONCLUSIONS}

Use of mid-estuarine environments during larval development, followed by migration to outer estuarine areas, can be viewed as a growth/maturation optimization strategy likely to enhance individual smelt fitness. Higher mid-estuarine temperatures, coupled with sufficient ration, fuel initial growth. Growth then slows as metabolic demands increase with seasonal temperature changes and the onset of maturation. Migration of smelt out of the middle estuary would lower their metabolic demands, thereby allowing greater energy reserves for maturation at constant ration. Additionally, out-migration may result in lower densities, thereby limiting intra-specific competition. Although smelt migration patterns are not explicitly known, our data imply that smelt migration in the Thames estuary is driven by short-term variations in the suitability of the thermal habitat. The thermally driven growth relationship suggests that climate fluctuations will affect the timing of peak smelt abundances in the estuary, influence apparent overall abundances and limit the suitability of smelt as on overall indicator of estuarine water quality. 
Acknowledgements. We thank the Environment Agency for permission to analyse and publish the data. Support for completion of this work was provided by a Natural Sciences and Engineering Research Council (Canada) research grant to M.P.

\section{LITERATURE CITED}

Attrill MJ, Power M (2000) Modelling the effect of drought on estuarine water quality. Water Res 34:1584-1594

Attrill MJ, Power M (2002) Climatic influence on a marine fish assemblage. Nature 417:275-278

Attrill MJ, Power M (2004) Partitioning of temperature resources amongst an estuarine fish assemblage. Estuar Coast Shelf Sci 61:725-738

Bates DM, Watts DG (1988) Nonlinear regression analysis and its applications. John Wiley \& Sons, New York

Bhattacharya CG (1967) A simple method of resolution of a distribution with gaussian components. Biometrics 23: 115-135

Biette RM, Geen GH (1980) Growth of underyearling sockeye salmon (Oncorhynchus nerka) under constant and cyclic temperature in relation to live zooplankton ration size. Can J Fish Aquat Sci 37:203-210

Blaxter JHS (1992) The effect of temperature on larval fishes. Neth J Zool 42:336-357

Brandt SB, Magnuson JJ, Crowder LB (1980) Thermal habitat partitioning by fishes in Lake Michigan. Can J Fish Aquat Sci 37:1557-1564

Brett JR (1979) Environmental factors and growth in fish. In: Hoar WS, Randall DJ, Brett JR (eds) Fish physiology, Vol VIII. Academic Press, London, p 599-675

Conover DO, Present TMC (1990) Countergradient variation in growth rate: compensation for length of the growing season among Atlantic silversides from different latitudes. Oecologia 83:316-324

Coutant CC (1976) Compilation of temperature preference data. J Fish Res Board Can 34:739-745

Dahlberg MD (1981) Nearshore spatial distribution of fishes in gillnet samples, Cayuga Lake, New York. J Gt Lakes Res 7:7-14

Dando PR (1984) Reproduction in estuarine fish. In: Potts GW, Wootton RJ (eds) Fish reproduction: strategies and tactics. Academic Press, London, p 155-170

Doherty D, McCarthy TK (2004) The ecology and conservation of European smelt (Osmerus eperlanus L.) from Waterford estuary, in southeastern Ireland. Proc R Irish Acad 104B:125-130

Driedzic WR, Ewart KV (2004) Control of glycerol production by rainbow smelt (Osmerus mordax) to provide freeze resistance and allow foraging at low winter temperatures. Comp Biochem Physiol B Biochem Mol Biol 139:347-357

Dryer WR (1966) Bathymetric distribution of fish in the Apostle Islands region, Lake Superior. Trans Am Fish Soc 95: 248-259

Elliott JM (1976) The energetics of feeding, metabolism and growth of brown trout (Salmo trutta L.) in relation to body weight, water temperature and ration size. J Anim Ecol 45: 923-948

Elliott M, O'Reilly MG, Taylor CJL (1990) The Forth estuary: a nursery and overwintering area for North Sea fishes. Hydrobiologia 195:89-103

Environment Canada (1982) Canadian climate normals, Vol 4. Degree days 1951-1980. Atmospheric Environment Service, Ottawa

Evans DO, Loftus DH (1987) Colonization of inland lakes in the Great Lakes region by rainbow smelt, Osmerus mor- dax: their freshwater niche and effects on indigenous fishes. Can J Fish Aquat Sci 44(Suppl 2):249-266

Haddon M (2001) Modelling and quantitative methods in fisheries. Chapman \& Hall/CRC, Boca Raton, FL

Horppila J, Nyberg K, Peltonen H, Turunen T (1996) Effects of five years of intensive trawling on a previously unexploited smelt stock. J Fish Biol 49:329-340

Hutchinson P, Mills DH (1987) Characteristics of spawningrun smelt, Osmerus eperlanus (L.), from a Scottish river, with recommendations for their conservation and management. Aquac Fish Manag 18:249-258

Ivanova MN (1980) On the life span of the smelt, Osmerus eperlanus, of Lake Beloye. J Ichthyol 20:91-98

Ivanova MN (1982) The influence of environmental conditions on the population dynamics of smelt, Osmerus eperlanus (Osmeridae). J Ichthyol 22:45-51

Ivanova MN, Volodin VM (1981) Variability in rate of sexual maturation in freshwater populations of smelt, Osmerus eperlanus. J Ichthyol 21:28-37

Jobling M (2002) Environmental factors and rates of development and growth. In: Hart JB, Reynolds JD (eds) Handbook of fish biology and fisheries, Vol 1. Blackwell Publishing, Oxford, p 251-266

Kafemann R, Thiel R, Sepúlveda A (1996) Die fischökologische Bedeutung der Nebenstromgewässer der Unterelbe. Arch Hydrobiol 110:199-214

Kennish MJ (1990) Ecology of estuaries, Vol 2. Biological aspects. CRC Press, Boca Raton, FL

Kinniburgh J (1998) Physical and chemical characteristics. In: Attrill MJ (ed) A rehabilitated estuarine ecosystem: the environment and ecology of the Thames Estuary. Kluwer Academic, Dordrecht, p 27-48

Kuznetsov VA (1976) The reproduction, distribution and growth of juveniles of non-commercial fish species in Siyaga Bay, Kuybyshev Reservoir. J Ichthyol 16:746-756

Magnuson JJ, Crowder LB, Medvick PA (1979) Temperature as an ecological resource. Am Zool 19:331-343

McKenzie RA (1964) Smelt life history and fishery in the Miramichi River, New Brunswick. Bull Fish Res Board Can 15:1313-1327

Mooij WM, Lammens EHRR, Van Densen WLT (1994) Growth rate of $0+$ fish in relation to temperature, body size and food in shallow eutrophic Lake Tjeukemeer. Can J Fish Aquat Sci 51:516-526

Munro M, Whitfield P, Lee S (1998) Host-parasite interactions: case studies of parasitic infections in migratory fish. In: Attrill MJ (ed) A rehabilitated estuarine ecosystem: the environment and ecology of the Thames Estuary. Kluwer Academic, Dordrecht, p 141-167

Næsje TF, Jonsson B, Klyve L, Sandlund OT (1987) Food and growth of age-0 smelts, Osmerus eperlanus, in a Norwegian fjord lake. J Fish Biol 30:119-126

Nellbring S (1989) The ecology of smelt (genus Osmerus): a literature review. Nord J Freshw Res 65:116-145

Nsembukya-Katuramu S, Balon EK, Mahon R (1981) A comparison of spawning, harvested, and die-off rainbow smelt, Osmerus mordax, in eastern Lake Erie. J Gt Lakes Res 7:144-154

Nyberg P, Bergstrand E, Degerman E, Enderlein O (2001) Recruitment of pelagic fish in an unstable climate: studies of Sweden's four largest lakes. Ambio 30:559-564

Ottersen G, Loeng H (2000) Covariability in early growth and year-class strength of Barents Sea cod, haddock, and herring: the environmental link. ICES J Mar Sci 57: 339-348

Pitcher JJ, Macdonald PDM (1973) Two models for seasonal growth in fishes. J Appl Ecol 10:599-606 
Power M, van den Heuvel MR (1999) Variability in YOY yellow perch growth and its relationship to temperature. Trans Am Fish Soc 128:687-700

Power M, Attrill MJ, Thomas RM (2000) Temporal abundance patterns and growth of juvenile herring and sprat from the Thames estuary 1977-1992. J Fish Biol 56:1408-1426

Pronier O, Rochard E (1998) Fonctionnement d'une population d'éperlan (Osmerus eperlanus, Osmériformes Osmeridae) située en limite méridionale de son aire de répartition, influence de la température. Bull Fr Pêche Piscic 350-51:479-497

Sims DW, Wearmouth VJ, Genner MJ, Southward AJ, Hawkins SJ (2004). Low-temperature-driven early spawning migration of a temperate marine fish. J Anim Ecol 73:333-341

Stearns SC (1992) The evolution of life histories. Oxford University Press, Oxford

Strelnikova AP, Ivanova MN (1982) Feeding of smelt, Osmerus eperlanus (Osmeridae), in early ontogenesis in the Rybinsk reservoir. J Ichthyol 25:48-54

Thiel R (2001) Spatial gradients of food consumption and production of juvenile fish in the lower River Elbe. Arch Hydrobiol Suppl 135:441-462

Thiel R, Potter IC (2001) The ichthyofaunal composition of the Elbe estuary: an analysis in space and time. Mar Biol 138: 603-616

Thomas RM (1998) Temporal changes in the movements and abundance of Thames estuary fish populations. In: Attrill

Editorial responsibility: Konstantinos Stergiou (Contributing Editor), Thessaloniki, Greece
MJ (ed) A rehabilitated estuarine ecosystem: the environment and ecology of the Thames Estuary. Kluwer Academic, Dordrecht, p 115-140

Thorpe JE, Adams CE, Miles MS, Keay DS (1989) Some photoperiod and temperature influences on growth opportunity in juvenile Atlantic salmon, Salmo salar L. Aquaculture 82:112-126

Tin HT, Jude DL (1983) Distribution and growth of larval rainbow smelt in eastern Lake Michigan, 1978-1981. Trans Am Fish Soc 112:517-524

Tracy CR, Christian KA (1986) Ecological relations among space, time, and thermal niche axes. Ecology 67: $609-615$

Trella K (2003) The growth rate of the six selected fish species inhabiting in the Polish part of the Vistula Lagoon. Bull Sea Fish Inst 160:61-73

Wheeler A (1979) The tidal Thames: the history of a river and its fishes. Routledge \& Keegan Paul, London

Wildhaber ML, Crowder LB (1990) Testing a bioenergeticsbased habitat choice model: bluegill (Lepomis macrochirus) responses to food availability and temperature. Can J Fish Aquat Sci 47:1664-1671

Zar JH (1999) Biostatistical analysis, 4th edn. Prentice-Hall, Upper Saddle River, NJ

Žiliukiene V (2002) The occurrence, food and size structure of smelt (Osmerus eperlanus L.) larvae in the Lithuanian part of the Curonian Lagoon. Bull Sea Fish Inst 156:33-43

Submitted: October 24, 2005; Accepted: June 8, 2006

Proofs received from author(s): January 11, 2007 